\title{
THE APPLICATION OF MICROBIOLOGICAL BIOPREPARATIONS IN THE PROCESS OF WATER REMEDIATION OF THE DAM RESERVOIR IN GŁUCHÓW
}

\author{
Robert Mazur ${ }^{\bowtie}$ \\ Faculty of Mining Surveying And Environmental Engineering, AGH University of Science And Technology
}

\begin{abstract}
Aim of the study

Assessment of the revitalization process and achievement of the treatment effects intended in the process

Material and methods

The author carried out selected tests and performed a process evaluation along with other results from research laboratories. The research concerned measurements of bottom sediment thickness, water transparency and selected physicochemical analyzes of quality parameters of water from the reservoir during the revitalization process.
\end{abstract}

\begin{abstract}
Results and conclusions
The obtained results are very satisfactory, as a high level of reduction of bottom sediments was achieved, at some measuring points by over $1 \mathrm{~m}$. There was an improvement in water transparency; physical and chemical parameters did not show deterioration of water quality during the intensive biodegradation process of the organic fraction deposited in bottom sediments. Based on the results presented in the article, it can be stated that the microbiological revitalization processes carried out are very effective methods of purifying surface water pollution.
\end{abstract}

Keywords: water pollution, eutrophication process, lake bioremediation, microbiological biopreparation, water degradation, water remediation

\section{INTRODUCTION}

In the last decade, an intensive development of environmental biotechnology focused on the preparation of selected strains of effective microorganisms for efficient biodegradation of various organic pollutants is observed (Kaszycki et al., 2001). Even though many companies still offer universal biopreparations with a wide spectrum of action and numerous applications, many manufacturers produce mixtures dedicated and adapted to local conditions in polluted waters (Sitarek et al., 2017). Such an approach is much more effective in the process of treating certain types of nonspecific organic pollutants in surface water (Kaszycki et al., 2001). The method of microbiological bioremediation of water bodies belongs to relatively new methods of removing pollutants from surface waters. Based on experts' reports one can indicate numerous water bodies, where the above-mentioned method was applied as the main one, or as a supplementary one in the water treatment process (Zakaria et al., 2010; Sitarek et al., 2017; Donajewska et al., 2019).

e-mail: mazurrob@gmail.com 
Mazur R. (2020). The application of microbiological biopreparations in the process of water remediation of the dam reservoir in Głuchów. Acta Sci. Pol., Formatio Circumiectus, 19 (1), 81-95. DOI: http://dx.doi.org/10.15576/ASP.FC/2020.19.1.81

Bioremediation treatments in the dam reservoir on the Jeziorka River were carried out twice in subsequent vegetation periods (see: Fig. 3). One of the main objectives of the revitalization process of the reservoir in Głuchów was to achieve an appropriate water status and maintain the effect's durability in the coming years. However, none of the lake revitalization methods can guarantee the effect's durability if the sources of pollution are not eliminated (Diplock, et al., 2009). The reservoir is characterized by a significant share of emerged macrophytes in the littoral zone, so no additional planting of ecotones was required for increased nutrients uptake. Many authors described positive influence of natural and artificial ecotones on the self-purification processes in degraded waters and the minimization of pressure from organic pollutants and nutrients (Pieczytiska, 1990; Decamps et al., 1990; Faafeng and Roseth, 1993; Chengqing and Zhiwen, 1995; Wang et al., 2002; Wang and Yin., 2008). These types of natural conditions are particularly important during the period of intensive biodegradation of organic pollutants by microorganisms and the release of nutrients into water (Verhoeven et al., 2006; Gaglio et al., 2019). The effects of the process of microbiological revitalization are very scarcely described in scientific literature, despite the fact they have been applied for many years.
The main purpose of the research was to assess the effectiveness of microbiological preparations in the bioremediation of the Głuchów reservoir waters. The basis for this assessment were changes in basic physicochemical parameters $\left(\mathrm{BOD}_{5}, \mathrm{COD}, \mathrm{TSS}\right.$, selected nutrients concentration) of water in the reservoir and the thickness of the bottom sediment layer before and after application of the microbiological preparations.

Many experts emphasize that this method can, in the future, replace or significantly limit the application of expensive technologies of the purification of water bodies, i.e., dredging, silting, chemical elimination of nutrients, etc. The carried-out research was based on physicochemical parameters, nevertheless, the monitoring allows the assessment of the performed work.

\section{MATERIALS AND METHODS}

\section{The characteristics of the object}

In the article, the author assessed the efficiency of this method, referring to the object, which was a reservoir in Głuchów (the commune of Grójec). This artificial retention reservoir is a small and shallow lake. It is fed by the Jeziorka River and for several years showed degradation of water quality as a result of the intensive eutrophication process (see: Fig. 1). In 2017-2018, the local authorities took steps to improve water quality and reduce the bottom sediment. The expert assess-

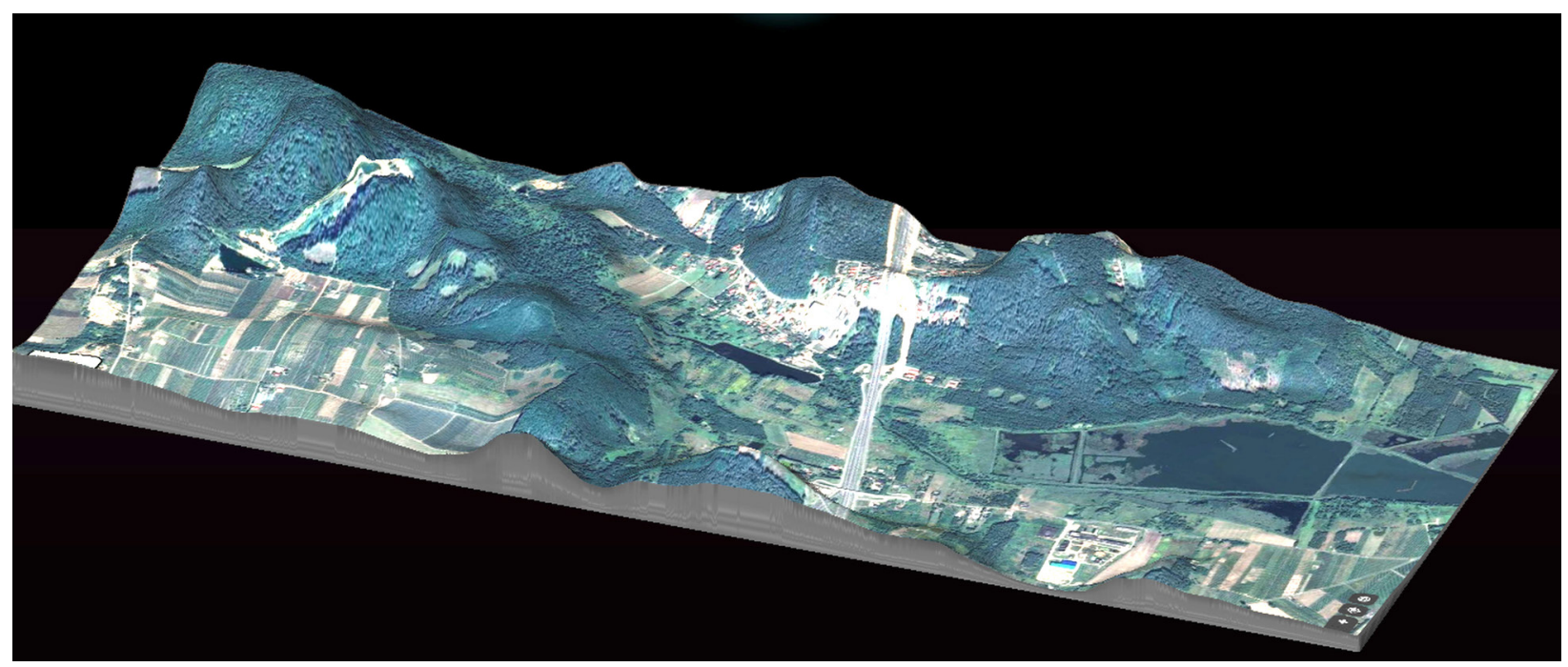

Fig. 1. 3D terrain model (projection) of the area in the vicinity of the dam reservoir in Głuchów (photo: R. Mazur). 
Mazur R. (2020). The application of microbiological biopreparations in the process of water remediation of the dam reservoir in Głuchów. Acta Sci. Pol., Formatio Circumiectus, 19 (1), 81-95. DOI: http://dx.doi.org/10.15576/ASP.FC/2020.19.1.81

ment indicated the choice of microbiological bioremediation method using liquid biopreparations.

The lake is located near an industrial wastewater treatment plant (treating sewage from a local winery) and in the immediate vicinity of an allotment garden. The reservoir is characterized by a very slow flow of water, which is why the water is stagnant (see: Table 1). Despite the discharge of treated sewage below the reservoir outflow, the migration of pollutants in the ground cannot be excluded (Chmielowski and Ślizowski, 2008; Mazur et al., 2016; Kaczor et al., 2017) (see: Fig. 2.).

Table 1. Morphometric characteristics of the reservoir

\begin{tabular}{cccccc}
\hline No. & $\begin{array}{c}\text { Name } \\
\text { of water } \\
\text { reservoir }\end{array}$ & $\begin{array}{c}\text { Surface } \\
\text { area } \\
{[\mathrm{ha}]}\end{array}$ & $\begin{array}{c}\text { Volume } \\
{\left[\mathrm{hm}^{3}\right]}\end{array}$ & $\begin{array}{c}\text { Depth [m] } \\
(\mathrm{avg} .-\mathrm{max})\end{array}$ & $\begin{array}{c}\text { Lake } \\
\text { types }\end{array}$ \\
\hline 1 & $\begin{array}{c}\text { Głuchów } \\
\text { Reservoir }\end{array}$ & 2.93 & 0.048 & $1.5-3$ & polymictic \\
\hline
\end{tabular}

Local authorities have made the reservoir available for fishery purposes, so it was stocked according to the preferences of fishermen. The environmental supervision inspector didn't have information regarding the stocking density and the number of fish introduced into the reservoir. For several years the reservoir wa- ters have undergone eutrophication due to their small size (especially lake depth) (Ligęza and Smal, 2005; Smal et al., 2013). The dominant species of helophytes in the coastal zone of the reservoir include common reed (Phragmites Australis), common bulrush (Typha latifolia), lesser bulrush (Typha angustifolia, L.), sweet flag (Acorus calamus), that is species with special abilities to bioaccumulate nutrients from the water and bottom sediments (Hammer and Bastian, 1989; Surrency, 1993; Greenway, 1997; Gopal, 1999; Stottmeister et al., 2003).

On the 3D model of the area around the reservoir, the area exposed to the influence of pollution from surface runoff into the Jeziorka catchment in front of the reservoir is presented (see: Fig. 1). Garden plots in the front of the reservoir are a nonpoint source pollution of rivers water (Baptista and Santos, 2017). The runoff of nutrients from these areas and crop protection products (such as pesticides) affect Jeziorka's waters (see: Fig. 1 and 2). The high-protein baits attracting fish were also a cause of organic pollution (in this shallow reservoir). In the scientific literature, there are reports on similar conditions, that cause the degradation of waters in the river catchments and require prompt actions to fight adverse effects of pollution from these sources (Arlinghaus and Niesar, 2005; Pawar, 2009; Friend, 2013).

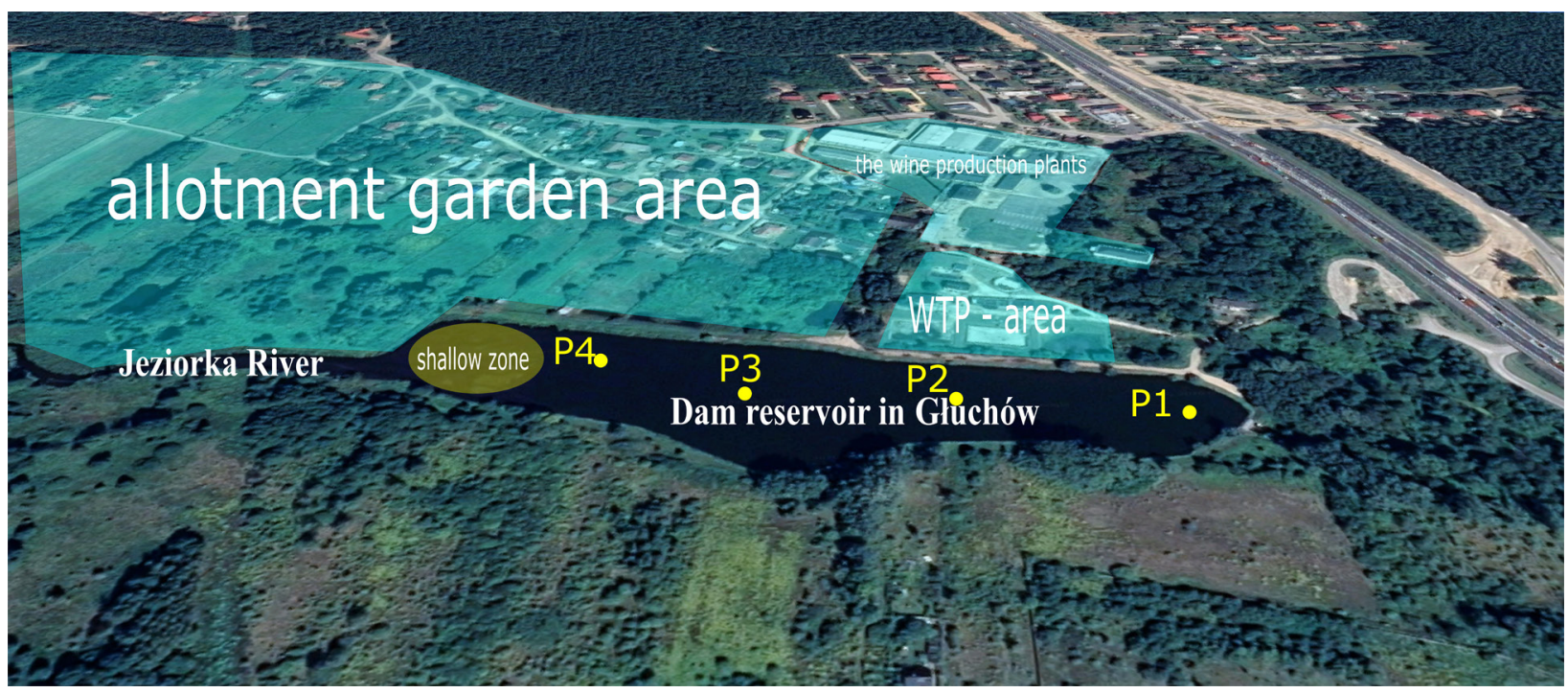

Fig. 2. Dam reservoir in Głuchów with measuring points and the area in the immediate vicinity (Source: Google maps - 3D satellite maps of Grójec area) 
Mazur R. (2020). The application of microbiological biopreparations in the process of water remediation of the dam reservoir in Głuchów. Acta Sci. Pol., Formatio Circumiectus, 19 (1), 81-95. DOI: http://dx.doi.org/10.15576/ASP.FC/2020.19.1.81

\section{THE COMPOSITION AND APPLICATION OF THE BIOPREPARATION}

Based on the physicochemical analysis of water, mixtures of starting biopreparations were selected and a dedicated microbiological mixture was made for the treatment purposes. The liquid biopreparations application process was carried out by the ACS Poland team, which has a biotechnology base for the adaptation of directional preparations. Liquid preparations have latent forms of a consortium of microorganisms, metabolic processes of which are activated very quickly and the start-up process is very short. The biomixtures were introduced in zones at various depths: in the surface layer, in the benthos zone, and into the sediment. Microorganisms during the period of adaptation to the new environment are particularly sensitive to UV radiation (Dejung et al., 2007), therefore the application took place during a period of low sunlight.

Three kinds of biopreparations used in the bioremediation of water bodies were applied: ACS1, ACS2, and ACS3. All the forms of biomixture contain main strains of lactic bacteria Lactobacillus plantarum, Lactobacillus rhamnosus, Lactobacillus casei, and Saccharomyces cerevisiae yeasts. Additionally, the ACS3 contains more strains of microorganisms applied in the food industry, of variable composition and stability. The medium for microorganisms is a dilution of molasses of sugar cane and a composition of micro- and macroelements (in the mineral form). Based on enviro,nmental samples, water with pollut- ants is added to biomixtures to adapt the microorganisms to specific pollutants (Charts of ACS characteristics). The process of technological adaptation and making the final form of biopreparation is know-how by ACS Poland.

The application was carried out once in June 2017 and repeated in June 2018 (see: Fig. 3). In 2017, the total of $4 \mathrm{~m}^{3}$ of the dilutions of biopreparations was added into the reservoir and distributed on a depth of $50 \mathrm{~cm}$ or multiplied (in deeper zones). Separately the mixtures were introduced to the silt with pressure lances with mild flow rate (in order not to move soft fractions). The dosing was repeated in the following vegetation season; the same volume of mixtures and the same system of distribution in water and near the bottom were applied.

\section{ANALYTICAL METHODS}

The measurement of the thickness of the soft, upper fraction of bottom sediments (with a significant share of organic matter) was made using the author's own method using an endoscopic camera. The image from the bottom examination is displayed on the computer monitor in online mode. In the examined reservoir, the measurement was made in the coastal zone of the lake and in its euphotic zone (up to the depth of $2.8 \mathrm{~m}$ ).

The sediment thickness was measured at 4 points P1 - P4 (see: Fig. 2). The measurements were carried out once in June 2017 (at 4 points), and thrice in oneweek intervals (at 4 points) in July 2018 and July 2019.

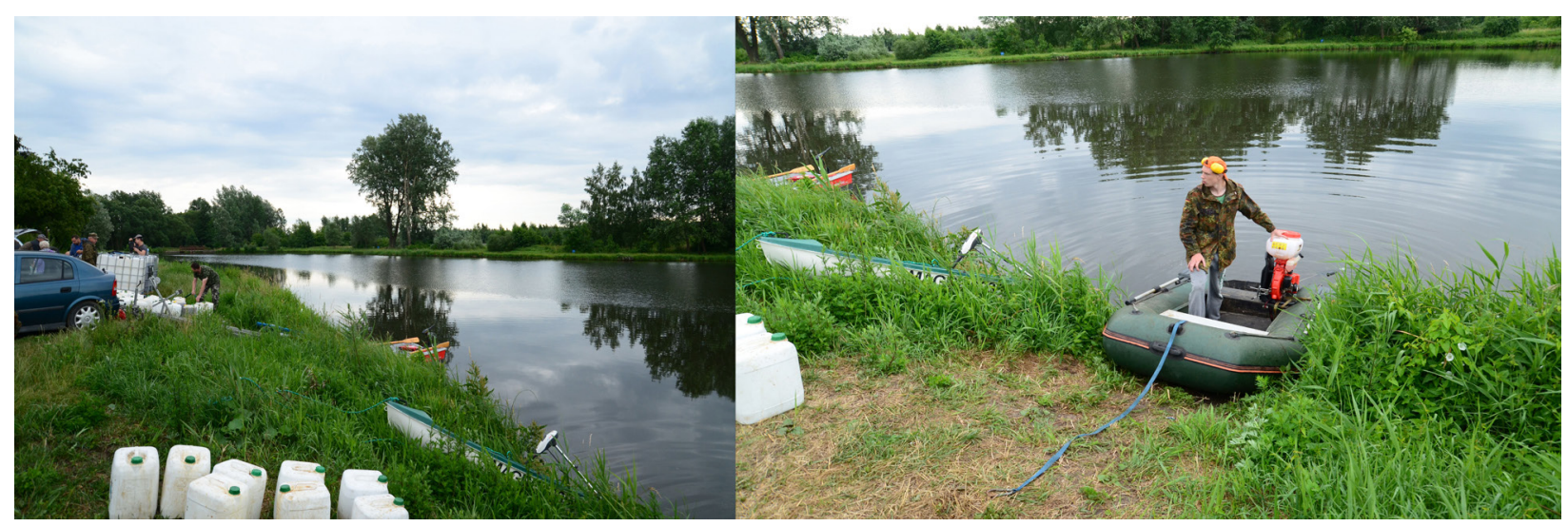

Fig. 3. The application of microbiological biopreparations mixtures into the water of the Głuchów Reservoir (phot. M. Sitarek) 
Mazur R. (2020). The application of microbiological biopreparations in the process of water remediation of the dam reservoir in Głuchów. Acta Sci. Pol., Formatio Circumiectus, 19 (1), 81-95. DOI: http://dx.doi.org/10.15576/ASP.FC/2020.19.1.81

The measuring points were located along the water flow way through the reservoir, in the pelagic and profundal zone (water samples were taken at a depth of $0.5 \mathrm{~m}$, and the thickness of the bottom sediment was measured) (see: Fig. 3). Water quality testing in this zone is most representative for the dam reservoir water.

The measurements were carried out once in June 2017 (at 4 points and 5 repetitions), thrice in one-week intervals (at 4 points and 5 repetitions) in July 2018 and in July 2019.

All tested parameters were analyzed according to the standards specified in Table 2.

The results are presented in the graphs as average values of tested physical and chemical parameters $\left(\mathrm{COD}, \mathrm{BOD}_{5}\right.$, TSS, selected form of nutrients concentration) with standard deviations (in error bars) (Fig. 4-10).

\section{Statistical analysis of obtained results}

One-way variance analysis was applied to check the statistical significance of differences between the results in subsequent years for the studied parameters. Analysis of correlation matrices between the studied parameters was also carried out. The analyses were carried out in the Statistica 13 and R (with R-Studio module) programs.

\section{RESULTS AND DISCUSSION}

The results of changes in the thickness of the bottom sediments (organic fraction) (see: Fig. 4) indicate significant progress in mineralization and reduction of the bottom sediment layer. At all measuring points, a decrease by more than a half to the initial state was demonstrated. At P2 and P3, it was a reduction of $1 \mathrm{~m}$ of bottom sediments during two vegetation periods (as a result of metabolic activity of microorganisms from applied biopreparations). The thickest layer of soft organic fractions of bottom sediments was in the central area of the water body, at points $\mathrm{P} 2=180 \mathrm{~cm}$ and P3 $=150 \mathrm{~cm}$ (see: Fig. 4). In this part of the reservoir, the water flow is the slowest due to morphometric and hydraulic conditions of the bowl, and water here is almost stagnant, thus the process of the sedimentation of suspended fractions is the most intensive (see: Fig. 3) (Schulz et al., 2003). At points $P 1=50 \mathrm{~cm}$ and $\mathrm{P} 4=70 \mathrm{~cm}$, also the fraction of soft bottom sediments was noticed, but both points are located in the areas where the cross section of the bowl is narrower, thus the speed flow is significantly greater than in the central area, and some fractions are still suspended and taken by the water flow (see: Fig. 3). The studies of the thickness of the sediment in the subsequent season of 2018, after the first application in 2017, showed

Table 2. Physicochemical analyzes of selected water quality parameters - list of methods used.

\begin{tabular}{|c|c|c|c|c|}
\hline Indication & Unit & Research Method & $\begin{array}{l}\text { The limit of } \\
\text { quantification }\end{array}$ & $\begin{array}{l}\text { Uncertainty expressed } \\
\text { as precision }\end{array}$ \\
\hline Basicity & $\mathrm{mmol} \cdot \mathrm{dm}^{-3}$ & PN-EN-ISO 9963-1: 2003 & & \\
\hline Permanganate index & $\mathrm{mgO}_{2} \cdot \mathrm{dm}^{-3}$ & PN-EN-ISO 8467: 2001 & \pm 0.6 & $1.2 \%$ \\
\hline $\mathrm{BOD}_{5}$ & $\mathrm{mgO}_{2} \cdot \mathrm{dm}^{-3}$ & $\begin{array}{l}\text { PN-EN-18899-1: } 2002 \\
\text { PN-EN-18899-2: } 2002\end{array}$ & \pm 4.5 & $11 \%$ \\
\hline $\mathrm{COD}-\mathrm{Cr}$ & $\mathrm{mgO}_{2} \cdot \mathrm{dm}^{-3}$ & ISO 15705 & & \\
\hline Ammonium Nitrogen & $\mathrm{mgNH}_{4} \cdot \mathrm{dm}^{-3}$ & ISO 7150 & \pm 0.08 & $1.7 \%$ \\
\hline Nitrite Nitrogen & $\mathrm{mgNO}_{2} \cdot \mathrm{dm}^{-3}$ & EN 26777 & \pm 0.02 & $1.5 \%$ \\
\hline Nitrate Nitrogen & $\mathrm{mgNO}_{3} \cdot \mathrm{dm}^{-3}$ & ISO 7890-1 & \pm 0.5 & $1.5 \%$ \\
\hline Total nitrogen & $\mathrm{mgN} \cdot \mathrm{dm}^{-3}$ & $\begin{array}{l}\text { EN-ISO 11905/1 } \\
\text { ISO } 7890-1\end{array}$ & \pm 0.5 & $1.3 \%$ \\
\hline Total phosphorus & $\mathrm{mgP} \cdot \mathrm{dm}^{-3}$ & EN-ISO 6878 & \pm 0.5 & $1.2 \%$ \\
\hline Total suspedned solids & $\mathrm{mg} \cdot \mathrm{dm}^{-3}$ & PN-EN 82: 2005 & & $2 \%$ \\
\hline
\end{tabular}


their reduction at all the measurement points. At central points $-\mathrm{P} 2$ and $\mathrm{P} 3$, was reduced to $130 \mathrm{~cm}$ and $120 \mathrm{~cm}$, respectively, while in P1 and P2 (localized closest to the inflow from the lake) (Fig. 4), the reduction was by $18 \mathrm{~cm}$ and $15 \mathrm{~cm}$, respectively. One can suggest that the flow speed, can also be significant for effective inoculation of the sediments by the application of microorganisms, which influences the efficiency of mineralization of these fractions in various parts of the lake. With higher speeds in the first stage, smaller number of microorganisms is able to dominate the structure of sediments (they are washed out and taken further) in the region of the largest cross-section, stagnant character of water stimulates effective inoculation of sediments (Battin and Sengschmitt, 1999; Fischer et al., 2003; Higashino and Stefan, 2005). In 2018 , biopreparations were applied in the reservoir, and the 2019 results of the measurements of organic fractions and bottom sediments confirm the trend of the earlier season. At central points, the obtained values were: $\mathrm{P}=88 \mathrm{~cm}$ and $\mathrm{P} 3=54 \mathrm{~cm}$, i.e. a reduction by about $1 \mathrm{~m}$ of sediments, as a result of intensive mineralization processes, referring to the base measurements of 2017. At points $\mathrm{P} 1$ and P4, a reduction by 20 and $18 \mathrm{~cm}$, respectively, was obtained, i.e. from $30 \mathrm{~cm}$ to $50 \mathrm{~cm}$ compared to the base measurements.

The increase in water transparency is directly proportional to the reduction of the level of suspended solids in water and can indicate a reduction in the intensity of the eutrophication process (see: Fig. 5 and 7) (Portielje and Van der Molen, 1999). Water transparency, measured in 2017 before the application, indicated the intensifying eutrophication processes and the algae bloom, limiting the penetration of light to a depth of about $30 \mathrm{~cm}$ at all the measurement points $\mathrm{P} 1-\mathrm{P} 4$. In the subsequent season, the measurements with the Secchi disc showed the improvement of transparency to $72-75 \mathrm{~cm}$, i.e. more than double in the season when the algae bloom is most intensive. It is a significant improvement of light permeability. It is also the result of metabolic activities of pelagic microorganisms. Latest measurements of 2019 showed further improvement by about $20 \mathrm{~cm}$ compared to the previous season, thus at all the points, the transparency reached about $90 \mathrm{~cm}$, which is three times the base measurement of 2017 . In many zones of the lake, where the depth doesn't exceed $90 \mathrm{~cm}$, the bottom was visible.

The level of easily and hardly biodegradable organic compounds in the reservoir waters (see: Fig. 6) did exceed the limit values for surface waters at many sampling points and remained at a very similar level (Journal of Laws Dz. U. 2016 pos. 1187). The activity of microorganisms mainly focused on the organic fractions of bottom sediments.

An increase in the concentration of ammonia and nitrite ions (see: Fig. 8) indicates the process of nitri-

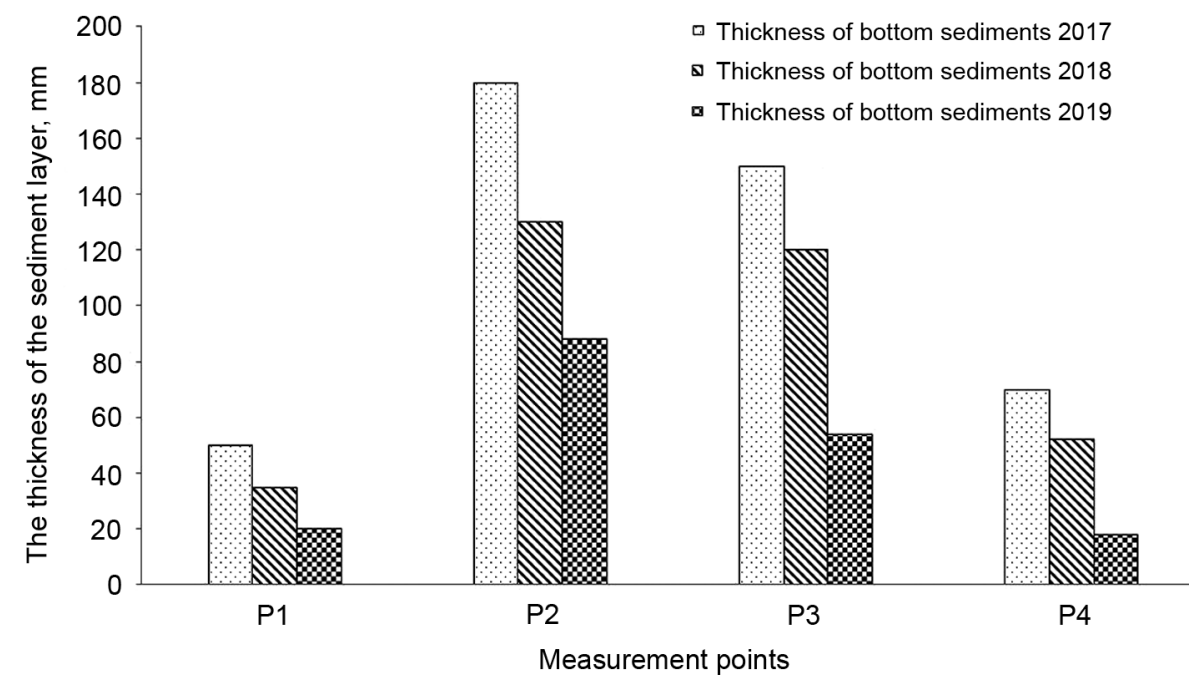

Fig. 4. Changes in the thickness of bottom sediments in 2017-2019 at points P1 - P4, measurements sampled in June 


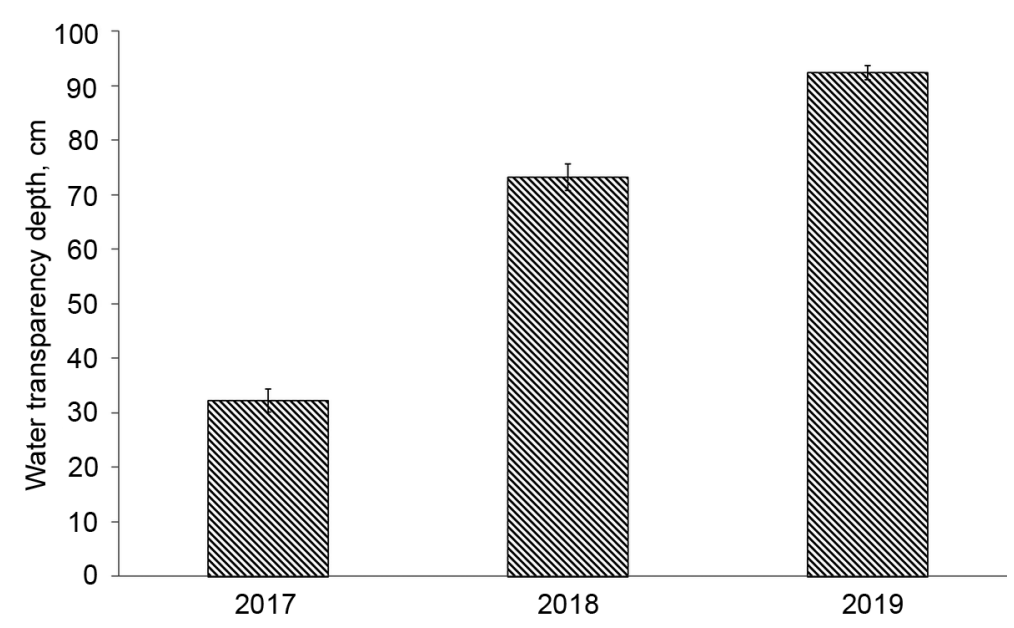

Fig. 5. Changes in water transparency in the years 2017-2019 (June), measured with a Secchi disk

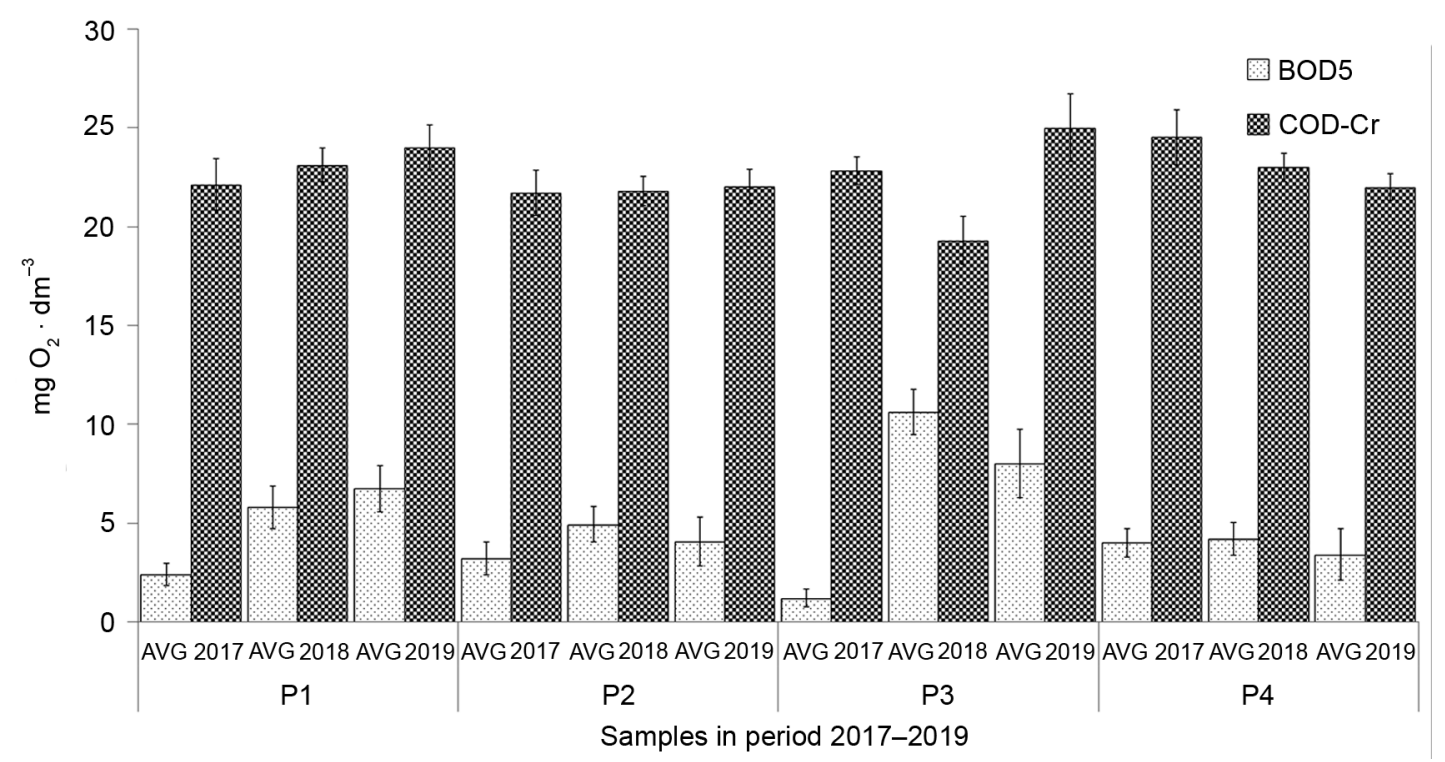

Fig. 6. Changes in $\mathrm{BOD}_{5}$ and COD values in June $2017-2019(\mathrm{AVG} \pm \mathrm{SD})$

fication and denitrification, due to intense metabolic changes in bottom sediments. They correspond to significant changes in the thickness of bottom sediments.

At each of the measurement points in the second vegetation season, the growth in total nitrogen was observed. After the second application, the studies showed its gradual decrease, correlating with the increase of water transparency (see: Fig. 9, Tab. 3).
The concentration of total phosphorus showed an upward trend after the first vegetation period since the application of the bio-mixtures (see: Fig. 10), analogous to the increase in mineral nitrogen forms (see: Figs. 8 and 9, Tab. 3). In the second period, the reduction of total phosphorus ions concentration in water was observed at three measuring points, despite intensive changes in sediments (see: Fig. 4). 


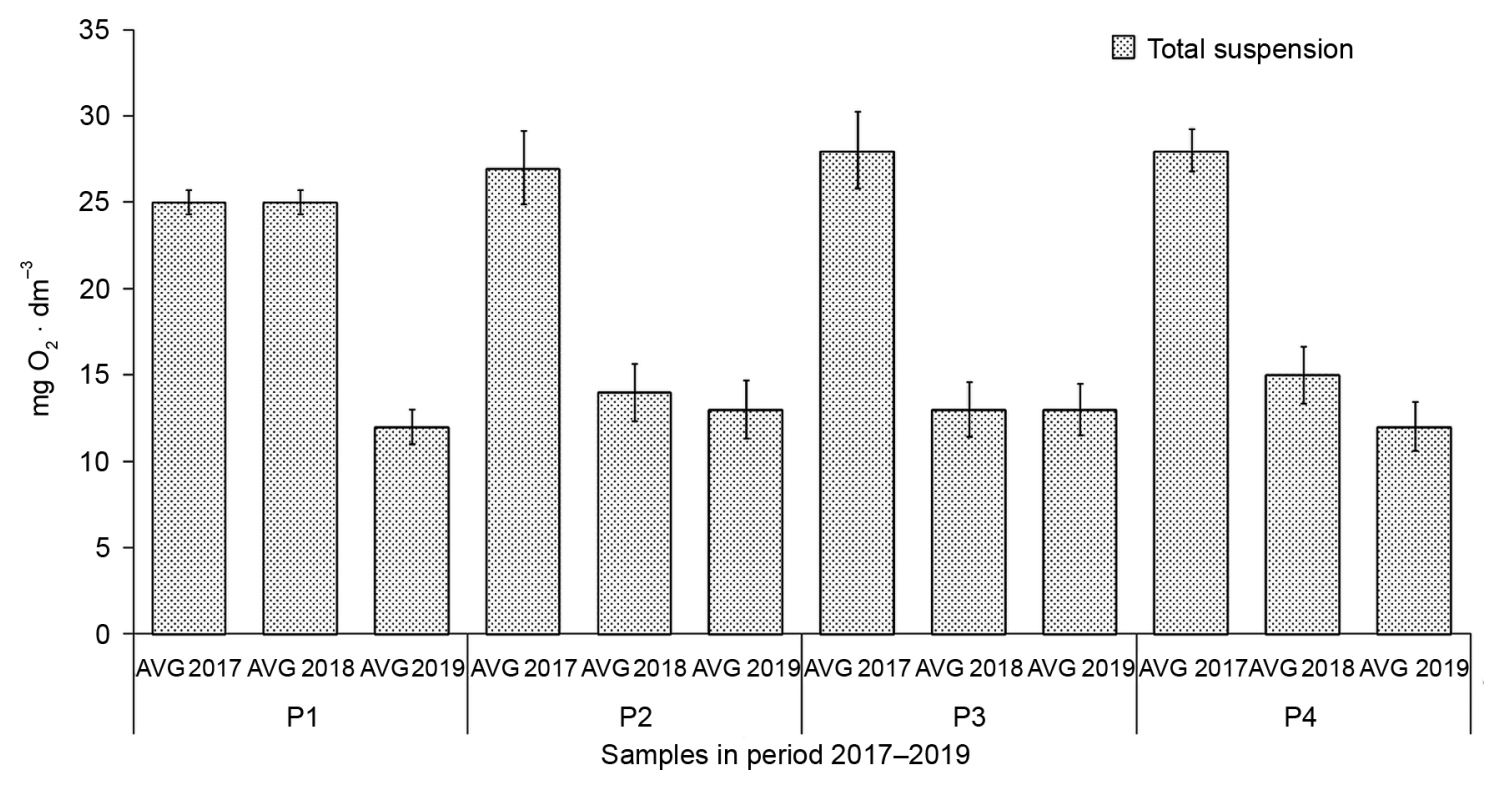

Fig. 7. Changes in suspension concentration during the sampling period (June) in $2017-2019$ (AVG \pm SD)

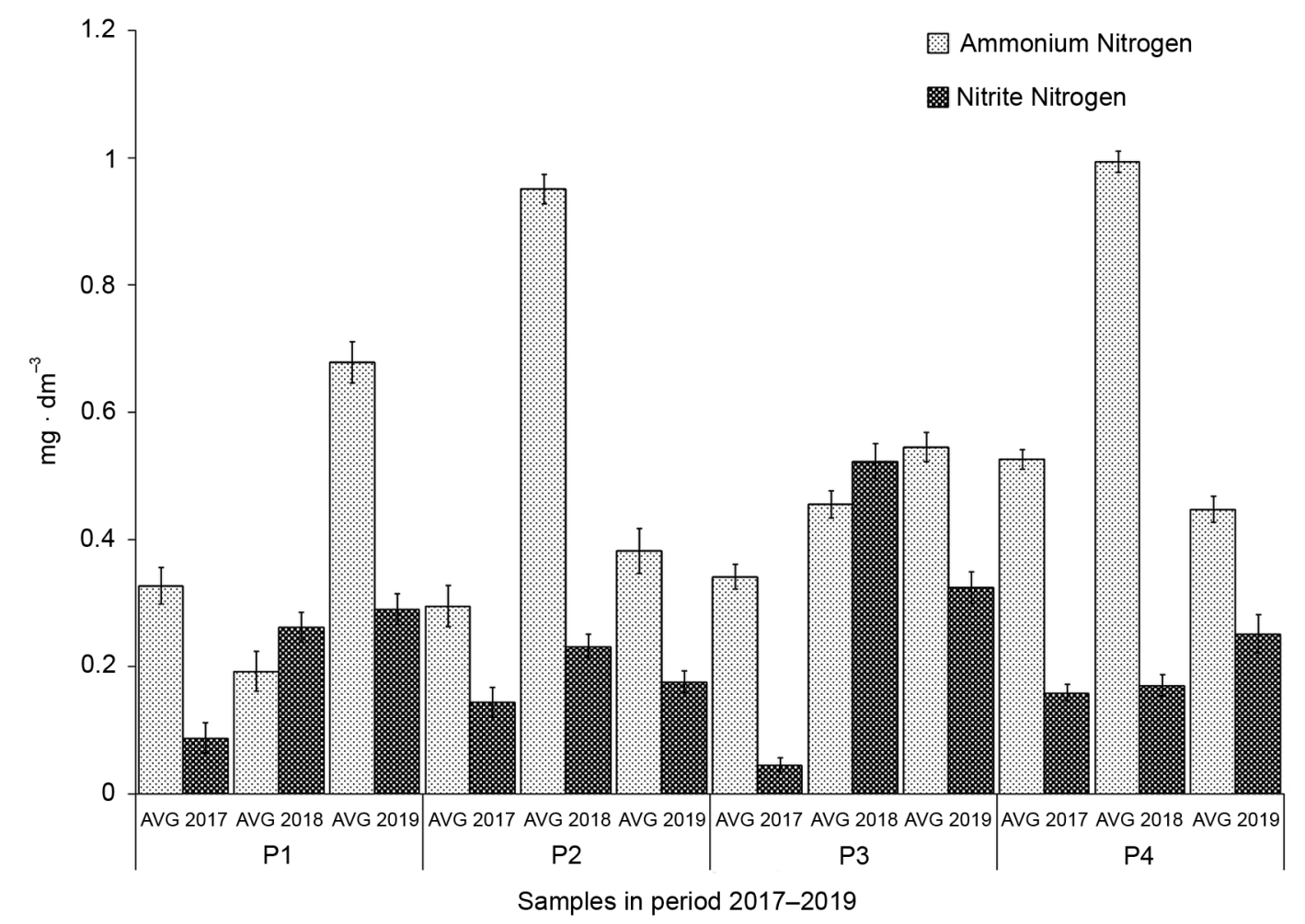

Fig. 8. Changes in the concentration of ammonia and nitrite ions in June (in 2017-2019 (AVG \pm SD)) 


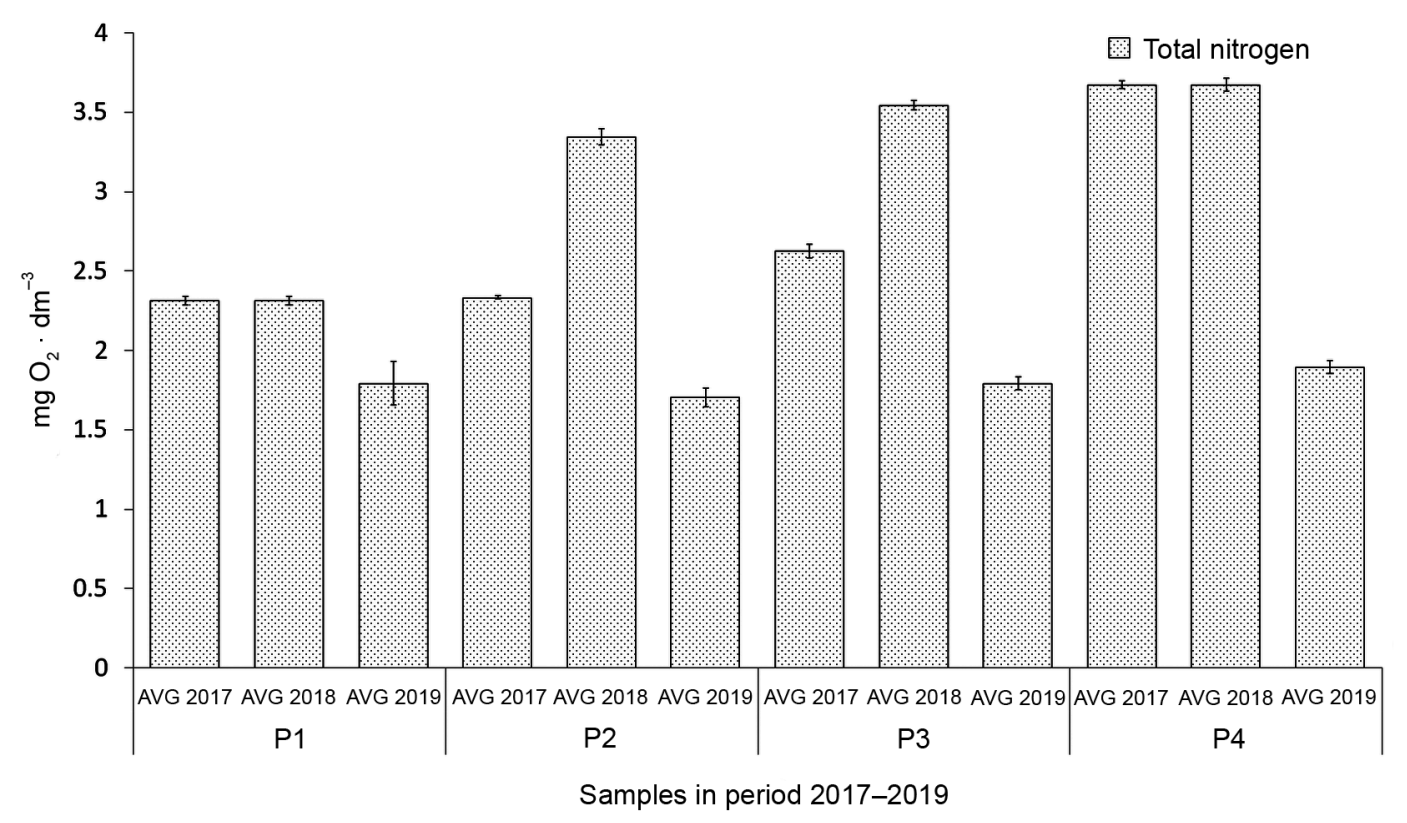

Fig. 9. Changes in the concentration of total nitrogen in June (in 2017-2019) (AVG \pm SD)

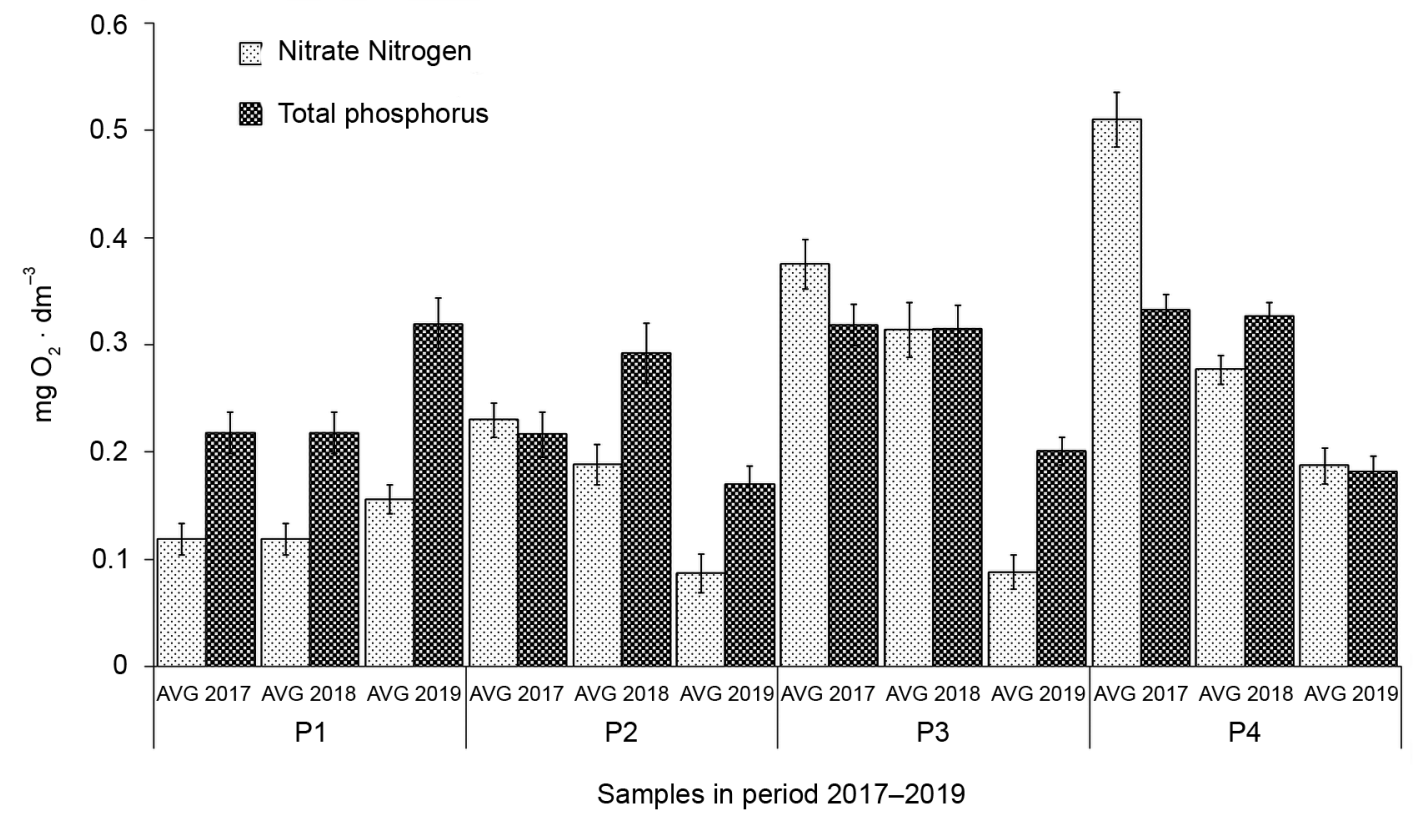

Fig. 10. Changes in total phosphorus and nitrate concentration in June (in 2017 and 2019) (AVG \pm SD) 
Mazur R. (2020). The application of microbiological biopreparations in the process of water remediation of the dam reservoir in Głuchów. Acta Sci. Pol., Formatio Circumiectus, 19 (1), 81-95. DOI: http://dx.doi.org/10.15576/ASP.FC/2020.19.1.81

\section{STATISTICAL ANALYSIS OF EVALUATED PARAMETERS}

The statistical analysis showed statistically significant differences between the average values of tested water parameters before biopreparation application in 2017 and the following years 2018 and 2019. The results of ANOVA tests showed differences in the tested groups for all monitored parameters (see: Table 4). Post hoc tests also indicated the significance of differences between the subsequent years for most tested parameters, except a few tests such as the ammonia nitrogen and
$\mathrm{BOD}_{5}$ for selected years (see: Table 5). The table with the correlation matrix showed significant relationships between the examined indicators (directly or inversely proportional) (see: Table 3). Strong correlation values were demonstrated between the $\mathrm{BOD}_{5}$ and $\mathrm{COD}$ parameters, as well as between the above-mentioned parameters and water transparency in the first year after bio-mixture application (inversely proportional). In the following year, these relationships dropped significantly (see: Table 3). For the remaining parameters, the correlation dependencies were significantly weaker or insignificant (see: Table 3).

Table 3. The correlation matrix between the variables (monitored physicochemical parameters)

\begin{tabular}{|c|c|c|c|c|c|c|c|c|c|}
\hline \multirow{3}{*}{ Variables } & \multicolumn{9}{|c|}{ Correlation (for 2018). The marked correlation coefficients are significant with } \\
\hline & \multicolumn{9}{|c|}{$p<0.05 ; N=60$} \\
\hline & $\mathrm{BOD}_{5}$ & COD & AMM & $\mathrm{NN}$ & NO & $\mathrm{TN}$ & $\mathrm{TP}$ & TSS & W-TRP \\
\hline $\mathrm{BOD}_{5}$ & 1 & -0.65 & -0.49 & 0.86 & 0.37 & 0.05 & 0.06 & -0.29 & 0.37 \\
\hline COD & -0.65 & 1 & 0.12 & -0.78 & -0.5 & -0.36 & -0.21 & 0.44 & -0.65 \\
\hline AMM & -0.49 & 0.12 & 1 & -0.49 & 0.27 & 0.75 & 0.36 & 0.05 & 0.43 \\
\hline $\mathrm{NN}$ & 0.86 & -0.78 & -0.49 & 1 & 0.48 & 0.14 & 0.07 & -0.4 & 0.48 \\
\hline NO & 0.37 & -0.5 & 0.27 & 0.48 & 1 & 0.8 & 0.62 & -0.26 & 0.49 \\
\hline $\mathrm{TN}$ & 0.05 & -0.36 & 0.75 & 0.14 & 0.8 & 1 & 0.59 & -0.21 & 0.69 \\
\hline $\mathrm{TP}$ & 0.06 & -0.21 & 0.36 & 0.07 & 0.62 & 0.59 & 1 & -0.11 & 0.25 \\
\hline TSS & -0.29 & 0.44 & 0.05 & -0.4 & -0.26 & -0.21 & -0.11 & 1 & -0.4 \\
\hline \multirow[t]{2}{*}{ W-TRP } & 0.37 & -0.65 & 0.43 & 0.48 & 0.49 & 0.69 & 0.25 & -0.4 & 1 \\
\hline & \multicolumn{9}{|c|}{ Correlation (for 2019). The marked correlation coefficients are significant with } \\
\hline \multirow[t]{2}{*}{ Variables } & \multicolumn{9}{|c|}{$p<0.05 ; N=60$} \\
\hline & $\mathrm{BOD}_{5}$ & COD & AMM & $\mathrm{NN}$ & NO & $\mathrm{TN}$ & $\mathrm{TP}$ & TSS & W-TRP \\
\hline $\mathrm{BOD}_{5}$ & 1 & 0.68 & 0.61 & 0.63 & -0.32 & -0.17 & 0.44 & -0.08 & 0.1 \\
\hline COD & 0.68 & 1 & 0.53 & 0.6 & -0.24 & -0.05 & 0.33 & -0.12 & 0 \\
\hline AMM & 0.61 & 0.53 & 1 & 0.68 & 0.23 & 0.12 & 0.87 & -0.21 & -0.2 \\
\hline $\mathrm{NN}$ & 0.63 & 0.6 & 0.68 & 1 & 0.13 & 0.26 & 0.44 & -0.08 & -0.45 \\
\hline $\mathrm{NO}$ & -0.32 & -0.24 & 0.23 & 0.13 & 1 & 0.58 & 0.27 & -0.35 & -0.77 \\
\hline $\mathrm{TN}$ & -0.17 & -0.05 & 0.12 & 0.26 & 0.58 & 1 & -0.05 & -0.23 & -0.66 \\
\hline $\mathrm{TP}$ & 0.44 & 0.33 & 0.87 & 0.44 & 0.27 & -0.05 & 1 & -0.21 & -0.06 \\
\hline TSS & -0.08 & -0.12 & -0.21 & -0.08 & -0.35 & -0.23 & -0.21 & 1 & 0.25 \\
\hline W-TRP & 0.1 & 0 & -0.2 & -0.45 & -0.77 & -0.66 & -0.06 & 0.25 & 1 \\
\hline
\end{tabular}


Mazur R. (2020). The application of microbiological biopreparations in the process of water remediation of the dam reservoir in Głuchów. Acta Sci. Pol., Formatio Circumiectus, 19 (1), 81-95. DOI: http://dx.doi.org/10.15576/ASP.FC/2020.19.1.81

Table 4. Analysis of variance of selected parameters value in period 2017-2019

\begin{tabular}{|c|c|c|c|c|c|c|}
\hline \multicolumn{7}{|c|}{ ANOVA } \\
\hline \multicolumn{3}{|c|}{ Df } & Sum Sq & Mean Sq & F value & $\operatorname{Pr}(>F)$ \\
\hline \multirow{2}{*}{ AMM } & Groups & 2 & 1.287 & 0.6433 & 11.22 & $3.08 \mathrm{E}-05$ \\
\hline & Residuals & 137 & 7.856 & 0.0573 & & \\
\hline \multirow{2}{*}{$\mathrm{BOD}_{5}$} & Groups & 2 & 173.1 & 86.53 & 17.29 & $2.02 \mathrm{E}-07$ \\
\hline & Residuals & 137 & 685.6 & 5 & & \\
\hline \multirow{2}{*}{ COD } & Groups & 2 & 64.7 & 32.34 & 10.39 & $6.28 \mathrm{E}-05$ \\
\hline & Residuals & 137 & 426.3 & 3.11 & & \\
\hline \multirow{2}{*}{$\mathrm{NN}$} & Groups & 2 & 0.5389 & 0.26943 & 26.54 & $1.81 \mathrm{E}-10$ \\
\hline & Residuals & 137 & 1.3908 & 0.01015 & & \\
\hline \multirow{2}{*}{$\mathrm{NO}$} & Groups & 2 & 0.5911 & 0.29554 & 46.59 & $3.67 \mathrm{E}-16$ \\
\hline & Residuals & 137 & 0.8691 & 0.00634 & & \\
\hline \multirow{2}{*}{$\mathrm{TN}$} & Groups & 2 & 62.47 & 31.237 & 187.5 & $<2 \mathrm{e}-16$ \\
\hline & Residuals & 137 & 22.82 & 0.167 & & \\
\hline \multirow{2}{*}{ TP } & Groups & 2 & 0.2152 & 0.1076 & 42.03 & $5.84 \mathrm{E}-15$ \\
\hline & Residuals & 137 & 0.3508 & 0.00256 & & \\
\hline \multirow{2}{*}{ TSS } & Groups & 2 & 3274 & 1637.1 & 586.8 & $<2 \mathrm{e}-16$ \\
\hline & Residuals & 137 & 382 & 2.8 & & \\
\hline \multicolumn{7}{|c|}{$\mathrm{AMM}$ - ammonia nitrogen, $\mathrm{NN}$ - nitrite nitrogen, $\mathrm{NO}$ - nitrate nitrogen } \\
\hline & & ogen & phosph & total sus & lids & \\
\hline
\end{tabular}

The dam reservoir in Głuchów, due to its small size, is particularly susceptible to the eutrophication process. Susceptibility to eutrophication processes for small and shallow reservoirs were widely described in the scientific literature (Camargo et al., 2005; Qin, 2009; Neverova-Dziopak and Kowalewski, 2013, 2014). The dam on the Jeziorka river disrupts the transporting process of river bed material and promotes the accumulation of pollution in the reservoir (Wei et al., 2009; Mazur et al., 2016). The shallowing process is a natural effect, while the accumulation of organic sediment layers results from the increased production of plant biomass due to the increase in the trophy of the Jeziorka waters (Brüchert et al., 2000; Frankowski at al., 2002). The flow of water through the reservoir is significantly slowed down and it has a stagnant character throughout the entire lake basin. The main problem for the lake was the accumulation of bottom sediment with high content of organic matter, layers of which exceeded the thickness of even 1 meter (see: Fig. 4). During the two vegetation periods, a volume reduction of more than half was observed at all measuring points (see: Fig. 2 and 4). The terrain conditions are relatively unfavorable for the reservoir, as surface runoff brings various types of pollution that accumulate in the lake (see: Fig. 1). Many authors have described similar dependencies of water reservoir degradation related to the emission of pollutants from the area and mixed sources ( $\mathrm{Ji}$ and Jeske, 2000; Duan et al., 2008; Kopacz et al., 2009; Kopacz and Twardy, 2012; Rajmund et al., 2018). Due to the significant amount of accumulated sediments over the years of the reservoir exploitation, the microbiological bioremediation process had to be repeated for two vegetation periods. Organic fractions are a source of food for microorganisms (Holguin et al., 2001), and by introducing them in high density, effective mineralization of residual organic pollution was obtained. The results of the water monitoring in 2017 did show slight excess of organic pollutants $\left(\mathrm{COD}\right.$ and $\left.\mathrm{BOD}_{5}\right)$ in the lake (see: Fig. 6), while the water transparency was significantly limited (see: Fig. 5) as a result of the increase of suspended solids (organic fractions and planktonic 
Mazur R. (2020). The application of microbiological biopreparations in the process of water remediation of the dam reservoir in Głuchów. Acta Sci. Pol., Formatio Circumiectus, 19 (1), 81-95. DOI: http://dx.doi.org/10.15576/ASP.FC/2020.19.1.81

Table 5. Tukey post hoc tests - fort ANOVA analysis results

"test HSD Tukeya" - Tukey multiple comparisons of means; $95 \%$ family-wise confidence level - for selected parameters (between years)

\begin{tabular}{|c|c|c|c|c|c|}
\hline & diff & lwr & upr & $\mathrm{p}$ & adj \\
\hline \multirow{3}{*}{ AMM } & 2017-2018 & 0.276 & 0.129 & 0.422 & 0.000 \\
\hline & 2017-2019 & 0.141 & -0.005 & 0.288 & 0.061 \\
\hline & 2018-2019 & -0.134 & -0.238 & -0.031 & 0.007 \\
\hline \multirow{3}{*}{$\mathrm{BOD}_{5}$} & 2017-2018 & 3.350 & 1.981 & 4.719 & 0.000 \\
\hline & 2017-2019 & 2.883 & 1.515 & 4.252 & 0.000 \\
\hline & 2018-2019 & -0.467 & -1.434 & 0.501 & 0.490 \\
\hline \multirow{3}{*}{ COD } & 2017-2018 & -0.997 & -2.076 & 0.083 & 0.077 \\
\hline & 2017-2019 & 0.457 & -0.622 & 1.537 & 0.576 \\
\hline & 2018-2019 & 1.454 & 0.691 & 2.217 & 0.000 \\
\hline \multirow{3}{*}{ NN } & 2017-2018 & 0.189 & 0.127 & 0.251 & 0.000 \\
\hline & 2017-2019 & 0.152 & 0.091 & 0.214 & 0.000 \\
\hline & 2018-2019 & -0.037 & -0.080 & 0.007 & 0.117 \\
\hline \multirow{3}{*}{$\mathrm{NO}$} & 2017-2018 & -0.078 & -0.127 & -0.029 & 0.001 \\
\hline & 2017-2019 & -0.179 & -0.228 & -0.130 & 0.000 \\
\hline & 2018-2019 & -0.101 & -0.136 & -0.067 & 0.000 \\
\hline \multirow{3}{*}{$\mathrm{TN}$} & 2017-2018 & 0.493 & 0.244 & 0.743 & 0.000 \\
\hline & 2017-2019 & -0.940 & -1.190 & -0.690 & 0.000 \\
\hline & 2018-2019 & -1.433 & -1.610 & -1.257 & 0.000 \\
\hline \multirow{3}{*}{$\mathrm{TP}$} & $2017-2018$ & 0.031 & 0.000 & 0.062 & 0.051 \\
\hline & 2017-2019 & -0.053 & -0.084 & -0.022 & 0.000 \\
\hline & 2018-2019 & -0.084 & -0.106 & -0.062 & 0.000 \\
\hline \multirow{3}{*}{ TSS } & 2017-2018 & -12.750 & -13.772 & -11.728 & 0.000 \\
\hline & 2017-2019 & -14.500 & -15.522 & -13.478 & 0.000 \\
\hline & 2018-2019 & -1.750 & -2.473 & -1.027 & 0.000 \\
\hline
\end{tabular}

$\mathrm{AMM}$ - ammonia nitrogen, $\mathrm{NN}$ - nitrite nitrogen, $\mathrm{NO}$ - nitrate nitrogen

$\mathrm{TN}$ - total nitrogen, TP - total phosphorus, TSS - total suspended solids algae biomass) in the water (see: Fig. 7) (Journal of Laws Dz. U. 2016 pos. 1187). These are typical effects of increased primary production when the supply of limiting elements ( $\mathrm{P}$ and $\mathrm{N}$ ) is exceeded (Qin, 2009;). It is difficult to indicate the impact of wastewater on the quality of water in the reservoir, but percolation of sewage from wastewater treatment plants cannot be excluded. There are many reports in the literature about the impact of sewage on surface water quality (Chmielowski and Bugajski, 2008; Miernik and Wałęga; 2008; Bugajski et al., 2016). Nutrients monitored during the bioremediation process did not show significantly excessive status (see: Fig. 8-10) (Journal of Laws Dz.U. 2016 pos. 1187). Slight decreases of ammonium compounds or total phosphorus were noted at some points (see: Fig. 9 and 10) and at other points there were slight increases (see: Fig. 9 and 10). Many authors described a significant increase in nutrients during the biodegradation process of sludge and the process required the use of additional coagulants binding these elements to compounds that precipitate into inorganic sediments (Gibbs and Özkundakci 2011; Wąsik et al., 2017; Gibbs and Hickey 2018). In the case of the Gluchów reservoir, this effect did not take place due to the formation of macrophyte plants in the lake littoral zone, which functioned as a natural nutrient filter (accumulating them in their biomass during growth) (Wang et al., 2002; Wang and Yin., 2008). After the first season (in 2018), an increase in water transparency was noted (see: Fig. 5) and this trend was continued in the following season after repeating the application of biomixtures of EM into the lake. To some extent, macrophytes constituted competition for nutrients with algae in the euphotic zone of the water column (Engelhardt and Ritchie, 2001); when the reservoirs do not have an adequate zone of submerged vegetation, artificial planting of ecotones must be carried out (Stottmeister et al., 2003). In the area around the reservoir, a significant reduction of odor nuisance was noted. After the first season, no putrefactive odors from anaerobic decomposition of bottom sediments were noticed.

\section{CONCLUSIONS}

1. The microbiological bioremediation process has brought visible effects of improving the quality of water in the dam reservoir in Głuchów. 
Mazur R. (2020). The application of microbiological biopreparations in the process of water remediation of the dam reservoir in Głuchów. Acta Sci. Pol., Formatio Circumiectus, 19 (1), 81-95. DOI: http://dx.doi.org/10.15576/ASP.FC/2020.19.1.81

2. There was a visible reduction of the organic layer of bottom sediments as a result of microbial biodegradation (by strains in applied biomixtures).

3. In the euphotic zone, the light transmittance increased significantly with the improvement of water transparency.

4. Nutrient and organic pollutant concentrations did not exceed a level that negatively affects water quality.

5. The littoral zone of macrophytes constituted a natural filter capturing nutrients during the period of their increased supply in the process of biodegradation of the organic fraction of bottom sediments.

7. The method of microbiological bioremediation is a very good alternative for restoring the ecological balance of water reservoirs (especially small ones) in comparison with other methods of polluted water remediation in lakes.

This paper was prepared within the scope of the research subsidy of the Ministry of Science and 6. Higher Education for AGH UST, no. 16.16.150.545

\section{REFERENCES}

Arlinghaus, R., Niesar, M. (2005). Nutrient digestibility of angling baits for carp, Cyprinus carpio, with implications for groundbait formulation and eutrophication control. Fisheries Management and Ecology, 12(2), 91-97

Baptista, C., Santos, L. (2016). Water quality monitoring in the Paul do Boquilobo Biosphere Reserve. Physics and Chemistry of the Earth, Parts A/B/C, 94, 180-187

Battin, T. J., Sengschmitt, D. (1999). Linking sediment biofilms, hydrodynamics, and river bed clogging: evidence from a large river. Microbial ecology, 37(3), 185-196

Brüchert, V., Pérez, M. E., Lange, C. B. (2000). Coupled primary production, benthic foraminiferal assemblage, and sulfur diagenesis in organic-rich sediments of the Benguela upwelling system. Marine Geology, 163(1-4), $27-40$

Bugajski, P., Chmielowski, K., Kaczor, G. (2016). Wpływ wielkości dopływu wód opadowych na skład ścieków surowych w małym systemie kanalizacyjnym. Acta Scientiarum Polonorum Formatio Circumiectus, 15(2), 3-11

Camargo, J. A., Alonso, Á., De la Puente, M. (2005). Eutrophication downstream from small reservoirs in mountain rivers of Central Spain. Water Research, 39(14), $3376-3384$
Chengqing, Y., Zhiwen, L. (1995). The nutrient retention by ecotone wetlands and their modification for Baiyangdian lake restoration. Water Science and Technology, 32(3), 159

Chmielowski, K., Ślizowski, R. (2008). Wpływ frakcji uziarnienia filtrów piaskowych o przepływie pionowym na stężenie wybranych zanieczyszczeń w ściekach oczyszczonych. Przemysł Chemiczny 5, 432-434

Chmielowski, K., Bugajski, P. (2008). Efektywność usuwania zanieczyszczeń w osadnikach gnilnych typu „Duofilter". Infrastruktura i ekologia terenów wiejskich, (05)

Decamps, G. P. H., Chauvet, E., Fustec, E. (1990). Functions of ecotones in fluvial systems. The ecology and management of aquatic-terrestrial ecotones, 4, 141

Dejung, S., Fuentes, I., Almanza, G., Jarro, R., Navarro, L., Arias, G., Birrer, C. (2007). Effect of solar water disinfection (SODIS) on model microorganisms under improved and field SODIS conditions. Journal of Water Supply: Research and Technology - AQUA, 56(4), 245-256

Diplock, E. E., Alhadrami, H. A., Paton, G. I. (2009). Application of microbial bioreporters in environmental microbiology and bioremediation. In Whole cell sensing system II (pp. 189-209). Springer, Berlin, Heidelberg

Dondajewska, R., Kozak, A., Rosińska, J., \& Gołdyn, R. (2019). Water quality and phytoplankton structure changes under the influence of effective microorganisms (EM) and barley straw-Lake restoration case study. Science of The Total Environment, 660, 1355-1366

Duan, X. J., Wang, S. G., \& Chen, W. (2008). Evolution of population distribution and growth shift in Changjiang River Delta. Sci Geogr Sin, 28(2), 139-144

Engelhardt, K. A., \& Ritchie, M. E. (2001). Effects of macrophyte species richness on wetland ecosystem functioning and services. Nature, 411(6838), 687-689

Faafeng, B. A., \& Roseth, R. (1993). Retention of nitrogen in small streams artificially polluted with nitrate. Hydrobiologia, 251(1-3), 113-122

Fischer, H., Sukhodolov, A., Wilczek, S., \& Engelhardt, C. (2003). Effects of flow dynamics and sediment movement on microbial activity in a lowland river. River Research and Applications, 19(5-6), 473-482

Frankowski, L., Bolałek, J., \& Szostek, A. (2002). Phosphorus in bottom sediments of pomeranian bay (Southern Baltic-Poland). Estuarine, Coastal and Shelf Science, 54(6), 1027-1038.

Friend, M. (2013). To conduct a chemical survey of the water quality at Borwick Fishery to justify the potential impact mass baiting may have on fish welfare (Doctoral dissertation). 
Mazur R. (2020). The application of microbiological biopreparations in the process of water remediation of the dam reservoir in Głuchów. Acta Sci. Pol., Formatio Circumiectus, 19 (1), 81-95. DOI: http://dx.doi.org/10.15576/ASP.FC/2020.19.1.81

Gaglio, M., Aschonitis, V., Pieretti, L., Santos, L., Gissi, E., Castaldelli, G., \& Fano, E. A. (2019). Modelling past, present and future Ecosystem Services supply in a protected floodplain under land use and climate changes. Ecological modelling, 403, 23-34

Gibbs, M. M., Hickey, C. W. (2018). Flocculants and Sediment Capping for Phosphorus Management. In Lake Restoration Handbook, 207-265. Cham: Springer

Gibbs, M., Özkundakci, D. (2011). Effects of a modified zeolite on $\mathrm{P}$ and $\mathrm{N}$ processes and fluxes across the lake sediment-water interface using core incubations. Hydrobiologia, 661(1), 21-35.

Gopal, B. (1999). Natural and constructed wetlands for wastewater treatement: potentials and problems. Water science and technology, 40(3), 27-35.

Greenway, M. (1997). Nutrient content of wetland plants in constructed wetlands receiving municipal effluent in tropical Australia. Water Science and Technology, 35(5), $135-142$.

Hammer, D. A., Bastian, R. K. (1989). Wetlands ecosystems: natural water purifiers. Constructed wetlands for wastewater treatment: municipal, industrial and agricultural, 5 .

Higashino, M., Stefan, H. G. (2005). Oxygen demand by a sediment bed of finite length. Journal of environmental engineering, 131(3), 350-358.

Holguin, G., Vazquez, P., Bashan, Y. (2001). The role of sediment microorganisms in the productivity, conservation, and rehabilitation of mangrove ecosystems: an overview. Biology and fertility of soils, 33(4), 265-278.

Ji, W., Jeske, C. (2000). Spatial modeling of the geographic distribution of wildlife populations: a case study in the lower Mississippi River region. Ecological modelling, 132(1-2), 95-104.

Kaczor G., Chmielowski K. Bugajski P. (2017). Wpływ sumy rocznej opadów atmosferycznych na objętość wód przypadkowych dopływających do kanalizacji sanitarnej, w: Annual Set The Environment Protection, Środkowo-Pomorskie Towarzystwo Naukowe Ochrony Środowiska, 19, 668-681

Kaszycki, P., Szumilas, P., Kołoczek, H. (2001). Biopreparat przeznaczony do likwidacji środowiskowych skażeń węglowodorami i ich pochodnymi. Inż. Ekol, 4, 15-22

Kopacz, M., Twardy, S. (2012). A spatial analyzis of biogenic load differentiation of an agricultural origin in the Carpathian basin areas. Polish Journal of Environmental Studies, 21(5A), 196-201

Kopacz, M., Twardy, S., Kowalczyk, A., Kuzniar, A. (2009). The structural changes of the Raba catchment area in the aspect of selected surface water quality parameters. Polish Journal of Environmental Studies, 18, 155-160
Ligęza, S., Smal, H. (2005). Spatial distribution of organic carbon and its long term changes in sediments of eutrophic dam reservoir "Zalew Zemborzycki”. ALVA-Mitteilung Heft, 3, 121-128.

Mazur, R., Bedla D., Chmielowski K., Nowak A. Mazurkiewicz J. (2016). Wpływ warunków tlenowych na skuteczność oczyszczania ścieków bytowych w technologii zatapialnych filtrów włókninowych, w: Przemysł Chemiczny, Wydawnictwo SIGMA - N O T Sp. z o.o., 96(8), 1513-1517, DOI:10.15199/62.2016.8.18

Mazur, R., Kałuża, T., Chmist, J., Walczak, N., Laks, I., Strzeliński, P. (2016). Influence of deposition of fine plant debris in river floodplain shrubs on flood flow conditions-The Warta River case study. Physics and Chemistry of the Earth, Parts A/B/C, 94, 106-113

Miernik, W., Wałęga, A. (2008). Anthropogenic influence on the quality of water in the Pradnik river. Environment Protection Engineering, 34(3), 103-108

Neverova-Dziopak, E., Kowalewski, Z. (2013). New approach to trophic state assessment of running waters in Poland. Meteorology Hydrology and Water Management. Research and Operational Applications, 1.

Neverova-Dziopak, E., Kowalewski, Z. (2014). Optymalizacja procedury oceny stanu troficznego wód przejściowych na przykładzie zalewu Szczecińskiego. Czasopismo Inżynierii Lądowej, Środowiska i Architektury, (61), 171-181.

Pawar, B. A. (2009). Studies on water quality and fish diversity of Sadatpur lake in Ahmednagar district Maharashtra. Journal of the Indian Fisheries Association, 36, 93-100.

Pieczytiska, E. (1990). Lentic aquatic-terrestrial ecotones: their structure, function and importance. The ecology and management of aquatic-terrestrial ecotones. MAB-Series, 4, 103-140.

Portielje, R., Van der Molen, D. T. (1999). Relationships between eutrophication variables: from nutrient loading to transparency. In Shallow Lakes' 98 (pp. 375-387). Dordrecht: Springer.

Qin, B. (2009). Lake eutrophication: control countermeasures and recycling exploitation.

Rajmund A., Czyżyk F., Paszkiewicz-Jasińska A., Kopacz M., 2018. The leaching of mineral nitrogen forms from light soil fertilized with compost and sewage sludge. Geology, Geophysics \& Environment, Akademia Górniczo-Hutnicza im. Stanisława Staszica w Krakowie. 44, 3, 319-327

Rozporządzenie Ministra Środowiska z dnia 21 lipca 2016 r. w sprawie sposobu klasyfikacji stanu jednolitych części wód powierzchniowych oraz środowiskowych norm 
Mazur R. (2020). The application of microbiological biopreparations in the process of water remediation of the dam reservoir in Głuchów. Acta Sci. Pol., Formatio Circumiectus, 19 (1), 81-95. DOI: http://dx.doi.org/10.15576/ASP.FC/2020.19.1.81

jakości dla substancji priorytetowych (Dz.U. 2016, poz. 1187).

Schulz, M., Kozerski, H. P., Pluntke, T., Rinke, K. (2003). The influence of macrophytes on sedimentation and nutrient retention in the lower River Spree (Germany). Water Research, 37(3), 569-578.

Sitarek, M., Napiórkowska-Krzebietke, A., Mazur, R., Czarnecki, B., Pyka, J. P., Stawecki, K., Kapusta, A. (2017). Application of Effective Microorganisms Technology as a lake restoration tool-A case study of Muchawka Reservoir-J. Elem, 22(2), 529-543.

Smal, H., Ligęza, S., Baran, S., Wójcikowska-Kapusta, A., Obroślak, R. (2013). Nitrogen and Phosphorus in Bottom Sediments of Two Small Dam Reservoirs. Polish Journal of Environmental Studies, 22(5).

Stottmeister, U., Wiessner, A., Kuschk, P., Kappelmeyer, U., Kästner, M., Bederski, O., Moormann, H. (2003). Effects of plants and microorganisms in constructed wetlands for wastewater treatment. Biotechnology advances, 22(1-2), 93-117.

Surrency, D. (1993). Evaluation of aquatic plants for constructed wetlands. Constructed Wetlands for Water Quality Improvement. Lewis Publishers, Boca Raton, FL, 349-357.
Verhoeven, J. T., Arheimer, B., Yin, C., Hefting, M. M. (2006). Regional and global concerns over wetlands and water quality. Trends in ecology \& evolution, 21(2), 96-103.

Wang, W., Yin, C. (2008). The boundary filtration effect of reed-dominated ecotones under water level fluctuations. Wetlands Ecology and Management, 16(1), 65-76.

Wang, W., Wang, D., Yin, C. (2002). A field study on the hydrochemistry of land/inland water ecotones with reed domination. Acta hydrochimica et hydrobiologica, 30(2-3), 117-127.

Wąsik E., Bugajski P., Chmielowski K., Nowak A., Mazur R. (2017). Crystallization of struvite and hydroxyapatite during removal of biogenic compounds on the filter bed, w: Przemysł Chemiczny, Wydawnictwo SIGMA - N O T Sp. z o.o., 96(8), 1739-1743.

Wei, G., Yang, Z., Cui, B., Li, B., Chen, H., Bai, J., Dong, S. (2009). Impact of dam construction on water quality and water self-purification capacity of the Lancang River, China. Water resources management, 23(9), 1763 -1780 .

Zakaria, Z., Gairola, S., Shariff, N. M. (2010). Effective microorganisms (EM) technology for water quality restoration and potential for sustainable water resources and management.

\section{ZASTOSOWANE BIOPREPARATÓW MIKROBIOLOGICZNYCH W PROCESIE REWITALIZACJI ZBIORNI- KA ZAPOROWEGO W GŁUCHOWIE}

\section{ABSTRAKT}

\section{Cel pracy}

Ocena procesu rewitalizacji oraz osiągnięcia zamierzonych w procesie efektów oczyszczania.

\section{Materiat i metody}

Autor przeprowadził wybrane badania oraz wraz z pozostałymi wynikami wykonanymi przez laboratoria badawcze wykonał ocenę procesu. Badania dotyczyły pomiarów miąższości osadów dennych, przejrzystości wody oraz wybrane analizy fizyko-chemiczne parametrów jakościowych wody ze zbiornika w trakcie procesu rewitalizacji.

\section{Wyniki i wnioski}

Uzyskane wyniki są bardzo zadowalające, gdyż osiagnnięto wysoki poziom redukcji osadów dennych w niektórych punktach pomiarowych o ponad $1 \mathrm{~m}$. Odnotowano poprawę przejrzystości wody, parametry fizyko-chemiczne nie wykazały pogorszenia się jakości wody trakcie intensywnego procesu biodegradacji frakcji organiki zalegającej w osadach dennych. Na postawie przedstawionych w artykule wyników można stwierdzić, iż prowadzone procesy rewitalizacji mikrobiologicznej należą do bardzo efektywnych metod oczyszczania zanieczyszczeń wód powierzchniowych.

Słowa kluczowe: zanieczyszczenia wód, oczyszczanie wody, bioremediacja jezior eutroficznych, proces eutrofizacji, biopreparaty mikrobiologiczne 